Integrative Systems

\title{
Labile Calcium-Permeable AMPA Receptors Constitute New Glutamate Synapses Formed in Hypothalamic Neuroendocrine Cells during Salt Loading
}

Shi Di, ${ }^{1}$ CZhiYing Jiang, ${ }^{1}$ Sen Wang, ${ }^{1}$ Laura M. Harrison, ${ }^{1}$ Eduardo Castro-Echeverry, ${ }^{1}$ Thomas C. Stuart, ${ }^{1}$ ํ) Marina E. Wolf, ${ }^{3}$ and ${ }^{(D)}$ Jeffrey G. Tasker ${ }^{1,2}$

https://doi.org/10.1523/ENEURO.0112-19.2019

${ }^{1}$ Department of Cell and Molecular Biology, Tulane University, New Orleans, LA 70118, ${ }^{2}$ Tulane Brain Institute, Tulane University, New Orleans, LA 70118, and ${ }^{3}$ Department of Neuroscience, Rosalind Franklin University of Medicine and Science, North Chicago, IL 60064

\section{Visual Abstract}

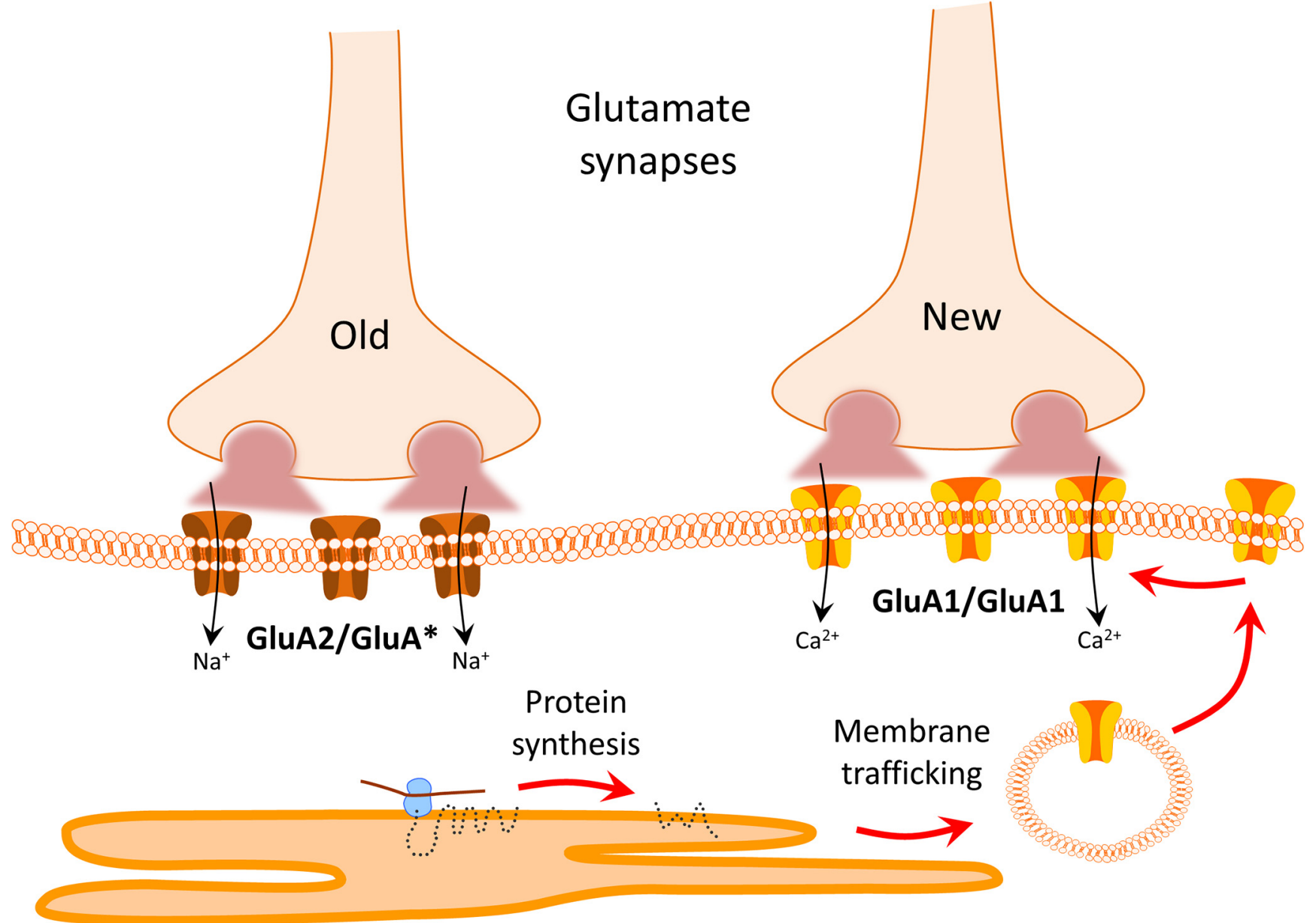




\section{Significance Statement}

Oxytocin (OT)- and vasopressin (VP)-secreting neurons of the hypothalamus undergo robust synaptic plasticity during chronic osmotic stimulation, including an increase in excitatory synapses. Here, we show that chronic salt loading results in the emergence of calcium-permeable AMPA receptor-mediated synaptic currents in OT and VP neurons by inducing an increase in GluA1 AMPA receptor subunits without a coordinate increase in GluA2 subunits. The salt loading-induced calcium-permeable AMPA currents were rapidly silenced by inhibiting protein synthesis and mammalian target of rapamycin (mTOR) activity, suggesting that continuous dendritic protein synthesis is required to functionally maintain the new AMPA synapses. Calcium influx through calcium-permeable AMPA receptors should play a key role in the induction and/or maintenance of synaptic plasticity in OT and VP neurons by chronic osmotic stimulation.

Magnocellular neuroendocrine cells (MNCs) of the hypothalamus play a critical role in the regulation of fluid and electrolyte homeostasis. They undergo a dramatic structural and functional plasticity under sustained hyperosmotic conditions, including an increase in afferent glutamatergic synaptic innervation. We tested for a postulated increase in glutamate AMPA receptor expression and signaling in magnocellular neurons of the male rat hypothalamic supraoptic nucleus (SON) induced by chronic salt loading. While without effect on GluA1-4 subunit mRNA, salt loading with $2 \%$ saline for 5-7 d resulted in a selective increase in AMPA receptor GluA1 protein expression in the SON, with no change in GluA2-4 protein expression, suggesting an increase in the ratio of GluA1 to GluA2 subunits. Salt loading induced a corresponding increase in EPSCs in both oxytocin (OT) and vasopressin (VP) neurons, with properties characteristic of calcium-permeable AMPA receptor-mediated currents. Unexpectedly, the emergent AMPA synaptic currents were silenced by blocking protein synthesis and mammalian target of rapamycin (mTOR) activity in the slices, suggesting that the new glutamate synapses induced by salt loading require continuous dendritic protein synthesis for maintenance. These findings indicate that chronic salt loading leads to the induction of highly labile glutamate synapses in OT and VP neurons that are comprised of calcium-permeable homomeric GluA1 AMPA receptors. The glutamate-induced calcium influx via calciumpermeable AMPA receptors would be expected to play a key role in the induction and/or maintenance of activity-dependent synaptic plasticity that occurs in the magnocellular neurons during chronic osmotic stimulation.

Key words: excitability; osmoregulation; oxytocin; paraventricular; supraoptic; vasopressin

\section{Introduction}

Magnocellular neuroendocrine cells (MNCs) in the rat hypothalamic supraoptic nucleus (SON) and paraven-

Received March 22, 2019; accepted June 21, 2019; First published July 12, 2019.

The authors declare no competing financial interests.

Author contributions: S.D., Z.J., S.W., L.M.H., E.C.-E., and T.C.S. performed research; S.D., Z.J., S.W., L.M.H., E.C.-E., T.C.S., and J.G.T. analyzed data; S.D., M.E.W., and J.G.T. wrote the paper; T.C.S. and J.G.T. designed research; M.E.W. contributed unpublished reagents/analytic tools.

This work was supported by National Institutes of Health Grants NS042081 (to J.G.T.) and DA009621 (to M.E.W.) and the Catherine and Hunter Pierson Chair in Neuroscience (J.G.T.).

Z. Jiang's present address: Institute of Molecular Medicine, University of Texas Health Sciences Center, Houston, TX 77054.

S. Wang's present address: Compeer Financial, Normal, IL 61761.

E. Castro-Echeverry's present address: Baylor Scott and White Medical Center, Temple, TX 76508.

T. C. Stuart's present address: PatentDive, Inc., New Orleans, LA 70119.

M. E. Wolf's present address: Department of Behavioral Neuroscience, Oregon Health and Science University, Portland, OR 97239.

Acknowledgements: We thank Dr. Katalin Smith and Mr. Mike Milovanovic for their expert technical assistance. We also thank the Department of Neuroscience of the Rosalind Franklin University of Medicine and Science for graciously hosting S.W. during the evacuation following hurricane Katrina.

Correspondence should be addressed to Jeffrey G. Tasker at tasker@ tulane.edu. tricular nucleus (PVN) play a critical role in the regulation of blood pressure, blood volume and sodium balance. The primary mechanism by which the brain regulates systemic osmotic homeostasis is through the release of vasopressin (VP) and oxytocin (OT) from hypothalamic MNC axons in the pituitary (Brownstein et al., 1980; Verbalis, 1993; Gainer and Wray, 1994). Under acute hypertonic conditions, both VP and OT neurons are activated (Poulain and Wakerley, 1982) and rapidly release VP and OT from the posterior lobe of the pituitary into the systemic blood circulation, from where the hormones access the kidney to regulate water reabsorption and salt excretion (Verbalis, 1993). Chronic osmotic stimulation induced by salt loading induces hypertension in the rat (Choe et al., 2015). Salt loading causes dramatic morphologic restructuring of the SON and PVN that includes hypertrophy and decreased astrocytic coverage of the magnocellular neurons. It also leads to significant morphologic and

https://doi.org/10.1523/ENEURO.0112-19.2019 Copyright (C) 2019 Di et al.

This is an open-access article distributed under the terms of the Creative Commons Attribution 4.0 International license, which permits unrestricted use, distribution and reproduction in any medium provided that the original work is properly attributed. 
functional synaptic plasticity, including increases in glutamatergic, GABAergic, and noradrenergic synaptic boutons on the magnocellular neurons, as well as increased glutamatergic signaling consistent with proliferation of glutamate release sites (Stern et al., 2000; Piet et al., 2002; Di and Tasker, 2004; Tasker et al., 2017) and enhanced glutamate receptor expression and/or function (Pak and Currás-Collazo, 2002).

Glutamate synapses make up a significant proportion of the synaptic innervation of the MNCs, representing $25 \%$ of all the SON synapses under basal conditions (Gribkoff and Dudek, 1988; van den Pol et al., 1990; Wuarin et al., 1992; Meeker et al., 1993, 1989). Glutamate AMPA receptors are tetramers comprised of combinations of four subunits, GluA1-4 (Borges and Dingledine, 1998; Dingledine et al., 1999). Expression of all four of the AMPA receptor subunits has been shown in the SON by immunohistochemistry and in situ hybridization (Nissen et al., 1994, 1995; Petralia et al., 1994; Hattori et al., 1998; Pak and Currás-Collazo, 2002). The ratio of GluA1-toGluA2 subunits determines many of the biophysical properties of native glutamate receptors, including receptor kinetics, single-channel conductance, calcium permeability, and voltage-dependent sensitivity to endogenous polyamines (Washburn et al., 1997). Thus, the GluA1-toGluA2 ratio is a major determinant of AMPA receptor function and is tightly regulated at the level of gene expression, RNA editing, receptor assembly, and receptor trafficking (Isaac et al., 2007).

The proliferation of glutamate synapses under conditions of chronic salt loading leads to increased excitatory synaptic innervation of the magnocellular neurons in the SON (Di and Tasker, 2004). Here, we postulated simply that the increase in functional excitatory innervation of these cells would be accompanied by a concomitant change in postsynaptic glutamate receptor expression and/or function. We combined quantitative polymerase chain reaction (qPCR), Western blotting, and membrane protein crosslinking analyses with whole-cell patch-clamp recordings in brain slices to test this hypothesis. Our findings revealed a more complex picture than anticipated, with newly formed glutamate synapses showing an apparent homomeric GluA1 AMPA receptor subunit composition and a highly labile expression that is dependent on continuous protein synthesis.

\section{Materials and Methods}

\section{Animals}

Adult male Sprague Dawley rats (Charles River) and VP-enhanced green fluorescent protein (eGFP) and OTmonomeric red fluorescent protein (RFP) Wistar transgenic rats were used in these studies (transgenic rats bred in-house, breeders kindly provided by Yoichi Ueta, Kitakyushu, Japan; Ueta et al., 2005; Katoh et al., 2011). All rats were group housed with ad libitum access to food and water, except for those undergoing salt loading. The salt-loading group was given access to only saline drinking water $(2 \% \mathrm{NaCl}, \mathrm{w} / \mathrm{v})$ for $5-7 \mathrm{~d}$; the euhydrated control group consisted of age-matched male rats receiving pure tap water. Animal weight was monitored and plasma os- molality was determined from trunk blood after decapitation. Animals in the salt-loaded group that did not show a marked increase in blood osmolality $(\geq 320 \mathrm{mOsm} / \mathrm{kg})$ were not included in the study. All experimental protocols were in accordance with United States Public Health Service guidelines and were approved by the Institutional Animal Care and Use Committees of Tulane University and the Rosalind Franklin University of Medicine and Science.

\section{Brain slice preparation}

Rats were anesthetized with isoflurane inhalation (Sigma) and decapitated in a rodent guillotine, and the brains were removed and immersed for 1-2 min in chilled $\left(0-1{ }^{\circ} \mathrm{C}\right)$ HEPES buffer-based artificial CSF (aCSF) composed of the following: $140 \mathrm{mM} \mathrm{NaCl}, 3 \mathrm{mM} \mathrm{KCl}, 1.5 \mathrm{mM}$ $\mathrm{MgSO}_{4}, 1.4 \mathrm{mM} \mathrm{NaH}_{2} \mathrm{PO}_{4}, 2.4 \mathrm{mM} \mathrm{CaCl}, 11 \mathrm{mM}$ glucose, and $5 \mathrm{mM}$ HEPES, saturated with $100 \% \mathrm{O}_{2}$. In some brain-slice experiments, we used a bicarbonate-based aCSF composed of the following: $124 \mathrm{mM} \mathrm{NaCl}, 2.7$ $\mathrm{mM} \mathrm{KCl}, 1.25 \mathrm{mM} \mathrm{NaH}_{2} \mathrm{PO}_{4}, 26 \mathrm{mM} \mathrm{NaHCO}, 1.3 \mathrm{mM}$ $\mathrm{MgSO}_{4}, 2.5 \mathrm{mM} \mathrm{CaCl}_{2}, 18 \mathrm{mM}$ glucose, and $2.25 \mathrm{mM}$ ascorbic acid, saturated with a $95 \% \quad \mathrm{O}_{2} / 5 \% \quad \mathrm{CO}_{2}$ gas mixture. The osmolarity was adjusted to $290-300$ mOsm and the $\mathrm{pH}$ was adjusted to 7.2-7.4. The hypothalamus was blocked on ice and hypothalamic slices of $300-\mu \mathrm{m}$ thickness were sectioned in cooled $\left(0-2^{\circ} \mathrm{C}\right)$, oxygenated aCSF with a vibrating slicer (Vibratome Series 1000; Technical Products, Intl.).

\section{qPCR}

For qPCR analyses, rats were anesthetized by isoflurane inhalation and then decapitated with a rodent guillotine. Whole brains were removed and quickly frozen in isopentane at $-40^{\circ} \mathrm{C}$ and stored at $-80^{\circ} \mathrm{C}$. On the day of experiments, 1-mm-diameter tissue punches of the SON were made from $300-\mu \mathrm{m}$-thick slices with a Miltex Biopsy Punch (Fig. 1A). Tissue samples were homogenized and RNA was isolated using the Aurum Total RNA Mini kit (Bio-Rad). An on-column DNase digestion step was performed to eliminate genomic DNA. RNA was then quantified with an Implen NanoPhotometer, and the RNA integrity was determined by agarose gel electrophoresis, which indicated intact RNA for all samples, without genomic DNA contamination. RNA (400 ng) was then reverse-transcribed with iScript Reverse Transcription Supermix (Bio-Rad) using random and oligo dT primers, and the cDNA was stored at $-20^{\circ} \mathrm{C}$. Negative control reactions were performed in the absence of reverse transcriptase enzyme. PCR with iTaq Universal SYBR Green Supermix (Bio-Rad) was performed in triplicate on a CFX thermocycler (Bio-Rad, 40 cycles). For each primer pair, a temperature gradient with annealing temperatures ranging from $55-70^{\circ} \mathrm{C}$ was tested, and $60^{\circ} \mathrm{C}$ was used for subsequent PCR reactions. The linear range and the efficiency were determined by performing a dilution curve for each primer pair consisting of eight 10 -fold dilutions. Efficiencies ranged from 100-110\%. PCR primer sequences and product sizes are shown in Table 1. Melt curves and agarose gel electrophoresis demonstrated single products for each reaction at the expected size. 
A

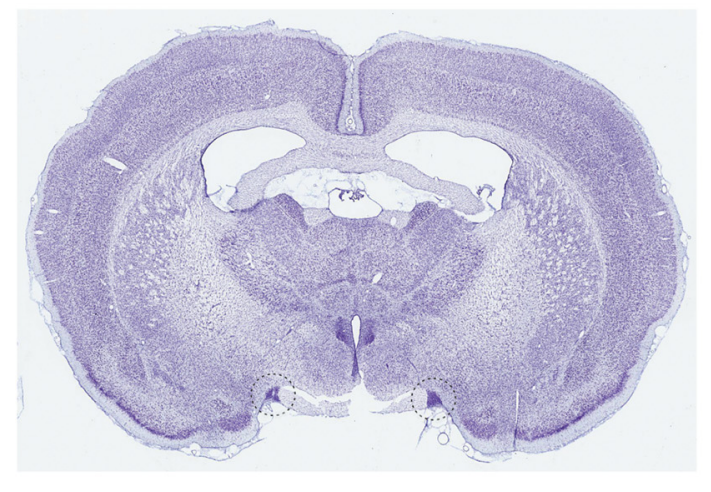

B

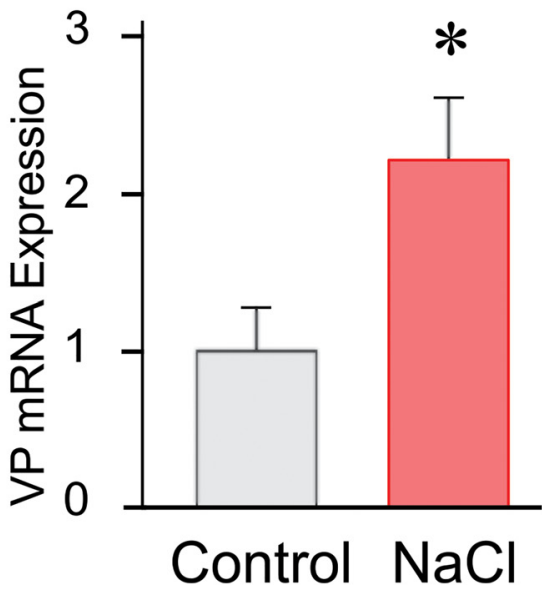

Figure 1. Effect of salt loading on VP mRNA expression in SON. $\boldsymbol{A}$, Image of a Nissl-stained coronal section of rat brain at the level of the hypothalamus showing the approximate locations of the 1-mm SON punches (dashed circles). $\boldsymbol{B}$, The relative VP mRNA expression measured by qPCR in SON punches from control (control) and salt-loaded (NaCl) rats, normalized to control; $* p<0.05$.

Data were analyzed by the $2^{-\Delta \Delta C}$ method. The geometric mean of cytochrome $\mathrm{C}-1$, cyclophilin, and GAPDH was used to normalize gene expression.

\section{Western blot}

For Western blot analyses, rats were deeply anesthetized with isoflurane, 300- $\mu \mathrm{m}$-thick brain slices were prepared as above, and 1-mm-diameter tissue punches of the SON were made with a Miltex Biopsy Punch using the optic chiasm/tracts as landmarks (Fig. 1). The SON tissue samples were added directly to lysis buffer $(20 \mathrm{mM}$ Tris, $\mathrm{pH} 8.0,137 \mathrm{nM} \mathrm{NaCl}, 10 \%$ glycerol, 1\% Nonidet P-40, and protease inhibitor cocktail) and homogenized. Lysates were clarified by centrifugation and protein was determined via a modified Lowry assay (DC Protein Assay, Bio-Rad). Samples (20- $\mu$ g total protein/lysate) were loaded onto Any kDa TGX Stain-Free gels (Bio-Rad) and electrophoresed under reducing conditions. Proteins were then transferred onto polyvinylidene fluoride mem- branes for immunoblotting. Membranes were blocked with $5 \%$ nonfat dry milk in TBS-Tween 20 (TBS-T) at $\mathrm{pH}$ 7.4 for $1 \mathrm{~h}$ at room temperature, followed by incubation with rabbit polyclonal antibody for GluA1 (1:500, AB1504; Millipore/Sigma), or GluA4 (1:500, AB1508; Millipore), or mouse monoclonal antibody for GluA2 (1:1000, MABN1189; Millipore/Sigma) or GluA3 (1:1000; MAB5416, Millipore) overnight at $4^{\circ} \mathrm{C}$. Membranes were then washed extensively with TBS-T solution, incubated for 60 min with HRP-conjugated anti-rabbit IgG or anti-mouse IgG (1: 1000; Cell Signaling Technologies, Danvers, MA or 1:10 000; Millipore Cell Signaling, Lake Placid, NY), and washed extensively again in the TBS-T solution. Following incubation in chemiluminescence detecting substrate (Clarity Western ECL Substrate, Bio-Rad), membranes were imaged on a ChemiDoc Imaging System (Bio-Rad). Image Lab software (Bio-Rad) was used to determine optical densities of individual bands, which were normalized to total protein on the blot.

Table 1. Primer pairs used for qPCR analysis

\begin{tabular}{|c|c|c|c|c|}
\hline Gene & $\begin{array}{l}\text { Accession } \\
\text { number } \\
\text { M25646 }\end{array}$ & $\begin{array}{l}\quad \text { Primer sequence (5' to } 3^{\prime} \text { ) } \\
\text { Forward: GCTGCTGCTTAGGCTGGTACA } \\
\text { Reverse: GGCGATGGCTCAGTAGACCC }\end{array}$ & $\begin{array}{l}\text { Product } \\
\text { size (bp) } \\
82\end{array}$ & Reference \\
\hline GluA2 & NM_017261 & $\begin{array}{l}\text { Forward: AGAGAAAGAATACCCTGGAGCACA } \\
\text { Reverse: TCATCACTTGGACAGCATCATACG }\end{array}$ & 80 & Primer3 \\
\hline GluA4 & NM_017263 & $\begin{array}{l}\text { Forward: AAACAGGCAAAGATAGGAGAAAGGG } \\
\text { Reverse: TCAGAGAGGCATTGAAGACGATGG }\end{array}$ & 129 & Primer3 \\
\hline GAPDH & $\mathrm{X} 02231$ & $\begin{array}{l}\text { Forward: ACATGCCGCCTGGAGAAACCT } \\
\text { Reverse: GCCCAGGATGCCCTITAGTGG }\end{array}$ & 90 & Kindlundh-Högberg et al. (2008) \\
\hline Cytochrome C-1 & NM_001277194 & $\begin{array}{l}\text { Forward: CTCTCCTCCTTGGACCACAC } \\
\text { Reverse: CGGTAAGCCACATAATCCA }\end{array}$ & 95 & Dachtler et al. (2014)* \\
\hline Cyclophilin & M19533 & $\begin{array}{l}\text { Forward: GAGCGTIITGGGTCCAGGAAT } \\
\text { Reverse: AATGCCCGCAAGTCAAAGAAA }\end{array}$ & 90 & Kindlundh-Högberg et al. (2008) \\
\hline
\end{tabular}

\footnotetext{
*Adapted for rat.
} 


\section{Membrane protein crosslinking}

Surface and intracellular levels of AMPA receptor subunits were quantified using a protein crosslinking method described previously (Boudreau et al., 2012). Briefly, cell surface-expressed proteins are covalently crosslinked using the membrane-impermeable, bifunctional crosslinker bis(sulfosuccinimidyl)suberate $\left(\mathrm{BS}^{3}\right)$. This increases the apparent molecular weight of crosslinked surface receptors recognized by the antibody, while intracellular receptors are not modified. Thus, surface and intracellular receptor pools can be separated and quantified using SDS-PAGE and immunoblotting. Brain slices prepared as described above were diced on a Mcllwain tissue chopper and were added to sample tubes containing $1 \mathrm{ml}$ of ice-cold aCSF, to which BS ${ }^{3}$ (Pierce) had been added just before the chopped tissue samples at a final concentration of $2 \mathrm{mM}$. Samples were incubated at $4^{\circ} \mathrm{C}$ for $30 \mathrm{~min}$ with gentle mixing. The crosslinking reaction was terminated by adding $100 \mu \mathrm{l}$ of $1 \mathrm{M}$ glycine stock solution, for a final glycine concentration of $100 \mathrm{mM}$, and then incubated at $4^{\circ} \mathrm{C}$ for $10 \mathrm{~min}$ with gentle mixing. The chopped tissue samples were then pelleted by centrifugation ( $2 \mathrm{~min}$ at $20,000 \times \mathrm{g}$ ) and the supernatant was discarded. Pellets were resuspended in 150- $\mu$ lice-cold lysis buffer containing protease and phosphatase inhibitors $25 \mathrm{mM}(\mathrm{pH} 7.4)$ HEPES, $500 \mathrm{mM} \mathrm{NaCl}, 2 \mathrm{mM}$ EDTA, $1 \mathrm{mM}$ DTT, $1 \mathrm{mM}$ phenylmethyl sulfonyl fluoride (PMSF), $20 \mathrm{mM} \mathrm{NaF}, 0.1 \%$ Nonidet P-40 (v/v), and $1 \times$ protease inhibitor cocktail] and homogenized rapidly by sonicating for $5 \mathrm{~s}$. Samples were then spun at 20,000 $\times g$ for 2 min and immediately placed on ice, aliquoted and stored at $-80^{\circ} \mathrm{C}$ until Western blot analysis was performed with $\beta$-actin as a loading control.

\section{Electrophysiology}

Brain slices were bisected down the midline and hemislices were incubated in warmed aCSF $\left(32-34^{\circ} \mathrm{C}\right)$ for recovery $(20 \mathrm{~min})$, then in oxygenated aCSF at room temperature for at least $1 \mathrm{~h}$ before recording. A single hemi-slice at a time was transferred to a submersion recording chamber mounted on a fixed-stage upright microscope (Olympus BX51WI) and continuously superfused at $2 \mathrm{ml} / \mathrm{min}$ with oxygenated aCSF at $31-32^{\circ} \mathrm{C}$.

Patch pipettes were pulled from borosilicate glass (1.65 $\mathrm{mm}$ outer diameter, $1.2 \mathrm{~mm}$ inner diameter; KG33; King Precision Glass) on a horizontal micropipette puller (Flaming/Brown P-97, Sutter Instruments) to a resistance of 3-5 $\mathrm{M} \Omega$, and were filled with a solution containing the following: $130 \mathrm{mM} \mathrm{K}$-gluconate, $1 \mathrm{mM} \mathrm{NaCl}, 1 \mathrm{mM} \mathrm{MgCl} 2,10$ mM EGTA, 2 mM Mg-ATP, $0.5 \mathrm{mM} \mathrm{Na-GTP,} 1 \mathrm{mM} \mathrm{CaCl}_{2}$, and $10 \mathrm{mM}$ HEPES. To study the current-voltage relations of AMPA receptor-mediated synaptic currents, a Cs-based, spermine-containing patch solution was used, composed of the following: $140 \mathrm{mM} \mathrm{CsCl}, 2 \mathrm{mM} \mathrm{MgCl}$, $10 \mathrm{mM}$ HEPES, $2 \mathrm{mM}$ Mg-ATP, $0.3 \mathrm{mM}$ Na-GTP, $2 \mathrm{mM}$ $\mathrm{QX} 314$, and $0.1 \mathrm{mM}$ spermine. The patch solution $\mathrm{pH}$ was adjusted to 7.3 and the osmolarity was adjusted to 300 mOsm.

Following transfer to the recording chamber, hemislices were allowed to equilibrate for at least $15 \mathrm{~min}$ before the start of recordings. SON neurons were visual- ized on a video monitor using a cooled CCD camera; infrared illumination and differential interference contrast (IR/DIC) optics, and were patch-clamped under visual control. After achieving the whole-cell configuration, series resistance and whole-cell capacitance were adjusted and monitored continuously throughout experiments. Magnocellular neurons were identified based on their location in the SON and their electrophysiological properties (i.e., robust A-type $\mathrm{K}^{+}$current and/or transient outward rectification (Tasker and Dudek, 1991; Luther et al., 2002). Recordings were performed in SON neurons from VP-eGFP and OT-RFP rats, in which VP-expressing neurons and OT-expressing neurons were identified, respectively, by their eGFP or RFP fluorescence under epifluorescence illumination before switching to IR/DIC to obtain patch-clamp recordings. Patch-clamp recordings were performed using a Multiclamp $700 \mathrm{~A}$ or $700 \mathrm{~B}$ amplifier (Molecular Devices). Data were low-pass filtered at 2 $\mathrm{kHz}$ with the amplifier and sampled at $10 \mathrm{kHz}$ using the pClamp 9 or 10 suite of software (Molecular Devices).

Slices were bathed in normal aCSF with picrotoxin $(50 \mu \mathrm{M})$ or bicuculline $(10 \mu \mathrm{M})$ to block $\mathrm{GABA}_{\mathrm{A}}$ receptor-mediated synaptic currents and DL-2-amino5-phosphonopentanoic acid (AP5; $40 \mu \mathrm{M}$ ) to block NMDA receptor-mediated currents. Changes in spontaneous EPSC (sEPSC) frequency, amplitude and decay time and evoked EPSC (eEPSC) amplitude and paired-pulse ratio were analyzed. The eEPSCs were elicited by extracellular electrical stimulation at $0.1 \mathrm{~Hz}$ at $50-70 \%$ of maximal amplitude via a concentric stimulating electrode (FHC) placed dorsal-medial to the SON. The paired-pulse stimulation paradigm was administered using a pair of identical electrical stimuli delivered at a 45-ms interval. We also recorded eEPSCs at holding potentials of $-60 \mathrm{mV}$ and $+40 \mathrm{mV}$ and with 20-mV incremented steps to calculate changes in inward rectification and to establish a current-voltage relationship, respectively. Averages of six individual eEPSC responses at each holding potential were used for analyses. I-V curves were normalized to the current response at $-60 \mathrm{mV}$ for comparison. The rectification index was determined by taking the ratio of the peak EPSC amplitudes recorded at $\mathrm{Vm}=-60 \mathrm{mV}$ to those recorded at $\mathrm{Vm}=+40 \mathrm{mV}$. Changes in capacitance, membrane resistance and series resistance were monitored continuously throughout the experiments. The series resistance at the beginning of recordings was $<20 \mathrm{M} \Omega$ and recordings were discarded if changes $>20 \%$ occurred during the recordings.

\section{Drug application}

The drugs used in electrophysiology experiments included the $\mathrm{GABA}_{\mathrm{A}}$ receptor antagonists picrotoxin (50 $\mu \mathrm{M})$ and bicuculline $(10 \mu \mathrm{M})$ to block inhibitory postsynaptic currents and the NMDA receptor antagonist AP5 $(40 \mu \mathrm{M})$ to isolate AMPA receptor-dependent EPSCs. 1-Naphthyl-acetyl-spermine (NAS; Hello Bio) was used to selectively inhibit GluA2-lacking/calcium-permeable AMPA receptor-mediated synaptic currents. The specific inhibitor of mammalian target of rapamycin (mTOR) rapa- 
mycin (Rapa; $500 \mathrm{nM}$ ), the selective inhibitor of eukaryotic protein synthesis cycloheximide $(\mathrm{CHX} ; 25 \mu \mathrm{M})$ and the gene transcription inhibitor actinomycin D (ACT; $25 \mu \mathrm{M}$ ) were applied extracellularly in the aCSF to preincubate the brain slices, and/or intracellularly during recordings via the patch pipette. All drugs, unless specified, were purchased from Tocris Bioscience.

\section{Statistical analyses}

Statistical analyses of data were performed using the Student's paired $t$ test for within-group comparisons and the student's unpaired $t$ test for between-group comparisons. A one-way or two-way ANOVA was used for multiple comparisons, followed by post hoc multiple comparisons with the Tukey's or Dunnett's test where appropriate. The significance threshold for all analyses was set at $p<0.05$. Statistical analyses were performed with Excel (Microsoft), Sigmaplot (Systat Software Inc.), or Prism (GraphPad Software). Data are expressed as the mean \pm SEM.

\section{Results}

Body weights were measured immediately before placing the salt-loaded animals on the $2 \%$ saline solution and the control animals on pure water and again after 5-7 d of saline or water consumption. Representative cohorts of control animals gained an average of $39 \%(n=8)$ and salt-loaded animals lost an average of $11 \%$ of their body weight $(n=10)$ by the end of the saline/water consumption period. Plasma osmolality measured at the end of the saline/water consumption period was $294.5 \pm 1.3$ $\mathrm{mOsm} / \mathrm{kg}$ in six control rats and $353.4 \pm 5.6 \mathrm{mOsm} / \mathrm{kg}$ in 19 salt-loaded rats (unpaired $t$ test, $t_{(23)}=5.6, p<0.001$ ).

\section{VP mRNA expression with salt loading}

Previous studies reported that VP mRNA expression undergoes a 1.5- to 2 -fold increase with salt loading (Van Tol et al., 1987; Sherman et al., 1988; Arnauld et al., 1993). Here, we used qPCR to test for changes in VP mRNA expression with salt loading and to serve as a positive control for our qPCR analyses. Salt loading caused a 2.2-fold increase in VP mRNA expression in SON samples $\left(t_{(16)}=2.4, p<0.05\right.$; Fig. 1).

\section{AMPA receptor subunit mRNA expression}

To determine whether the changes in glutamate synapse number and glutamate responses induced by chronic salt loading (Di and Tasker, 2004; Bonfanti and Theodosis, 2009) are accompanied by changes in AMPA receptor expression, we first conducted a qPCR analysis to test for an increase in the total expression of AMPA receptor subunit mRNA in chronically salt-loaded rats ( $n$ $=9)$ compared to control rats $(n=9)$. Our results confirmed previous findings that the mRNAs of each of the four AMPA receptor subunits are expressed in the SON (Petralia and Wenthold, 1992; Martin et al., 1993; Sato et al., 1993; Watanabe et al., 1993; van den Pol et al., 1994; Ginsberg et al., 1995; Al-Ghoul et al., 1997). Unexpectedly, there was no significant change in the mRNA expression of any of the AMPA receptor subunits with salt loading (unpaired $t$ test; GluA1: $t_{(16)}=1.3, p=0.21$;
GluA2: $t_{(16)}=1.8, p=0.09$; GluA3: $t_{(16)}=0.95, p=0.36$; GluA4: $t_{(16)}=1.4, p=0.19$; Fig. $2 A$ ).

The finding that none of the AMPA receptor subunits showed a significant increase in mRNA expression with salt loading suggested that the hypothesized upregulation of the glutamate receptor expression, if it occurs, must manifest at a post-transcriptional stage. We used a Western blot approach to test for this possibility of plasticity in protein expression of the AMPA receptor subunits with chronic salt loading.

\section{AMPA receptor subunit protein expression}

We measured AMPA receptor subunit protein levels in SON tissue homogenates from control $(n=8)$ and saltloaded rats $(n=7)$. In response to salt loading, GluA1 was the only subunit that showed a significant change in protein level, increasing by $69 \%$ (unpaired $t$ test, $t_{(13)}=$ 2.484, $p<0.05$; Fig. 2B). The GluA2 subunit protein level did not change $\left(t_{(13)}=0.236, p=0.817\right.$; Fig. $\left.2 B\right)$. The GluA3 and GluA4 protein levels also did not change $(p>$ 0.05 ; data not shown).

We next used a surface protein crosslinking approach (Boudreau et al., 2012) to compare cell surface versus intracellular pools of GluA1-GluA4 protein in SON samples. Using Western blot analysis of crosslinked surface protein and unmodified intracellular protein, we found that both the surface and intracellular GluA1 protein levels increased in the salt-loaded animals $(51 \%$ and $73 \%$ increase, respectively, compared to controls), although the increase in intracellular GluA1 did not reach statistical significance $(p=0.137$; Fig. $2 C)$. The surface and intracellular GluA2 protein levels did not change with salt loading (Fig. 2C), nor did the GluA3 and GluA4 protein levels (data not shown). Despite the change in total GluA1 protein, the relative membrane localization (i.e., $\mathrm{S} / \mathrm{I}$ ratio) of GluA1, as well as the other three AMPA receptor subunits, remained unchanged (Fig. 2D). Taken together with the increase in total GluA1 protein (Fig. $2 B$ ) and the lack of alteration in any of the subunit mRNAs (Fig. $2 A$ ), these results indicate a selective posttranscriptional increase in GluA1 protein in the SON after salt loading that is distributed proportionately between the intracellular and membrane compartments. This suggested an increase in the membrane GluA1-to-GluA2 AMPA receptor subunit ratio in SON neurons with salt loading, which should have significant effects on AMPA receptor signaling. We tested for this possibility using whole-cell patch-clamp recordings of SON magnocellular neurons in brain slices.

\section{Changes in excitatory synaptic inputs}

SON neurons recorded in slices from salt-loaded rats showed an increase in the frequency and amplitude of sEPSCs compared with SON neurons from control rats. In recordings of identified VP neurons in slices from VPeGFP rats, there was an increase of $60 \%$ in the mean sEPSC frequency, from $1.5 \pm 0.2$ to $2.4 \pm 0.2 \mathrm{~Hz}$ (unpaired $t$ test, $t_{(32)}=3.3, p<0.001$ ), and an increase of $14 \%$ in the mean sEPSC amplitude, from $21.1 \pm 1.2$ to $24.1 \pm 1.0 \mathrm{pA}\left(t_{(32)}=2.1, p<0.05\right)$, in VP neurons from salt-loaded rats compared to control rats (Fig. $3 A$ ). Similar findings were obtained from identified OT neurons re- 
A

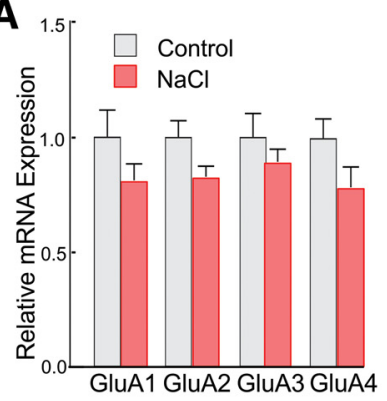

B1 GIUA1

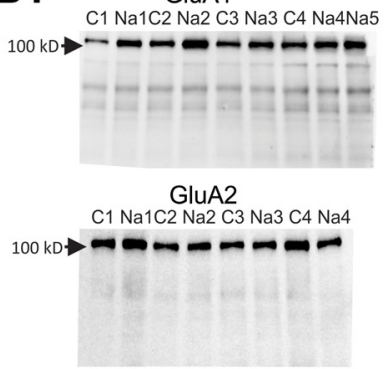

B2

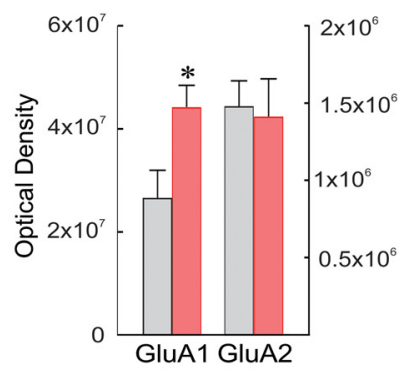

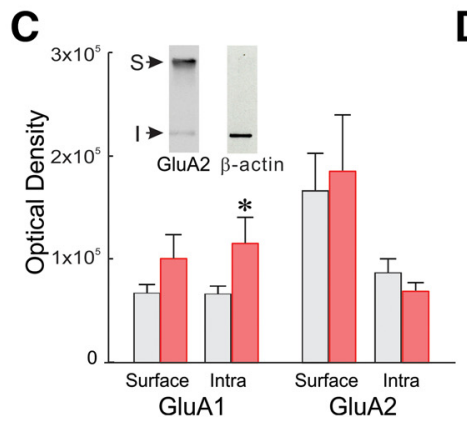

D

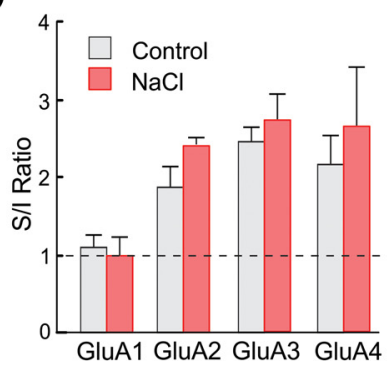

Figure 2. Effects of chronic salt loading on AMPA receptor subunit expression in the SON. $\boldsymbol{A}$, qPCR of AMPA receptor subunit mRNA expression in SON punches from control and salt-loaded $(\mathrm{NaCl})$ rats revealed no significant change in any of the AMPA receptor subunit mRNAs, GluA1-4, with salt loading. B1, Representative Western blots of GluA1 and GluA2 total protein expression in SON punches from four control rats (C1-C4) and five (GluA1: Na1-Na5) or four (GluA2: Na1-Na4) salt-loaded rats. B2, Mean optical density measurements of GluA1 and GluA2 protein bands from SON tissue from control $(N=8)$ and salt-loaded $(\mathrm{NaCl}, N=7)$ rats revealed an increase in total GluA1 protein with salt loading. $\boldsymbol{C}$, Surface and intracellular GluA1 and GluA2 protein levels in SON punches from control $\left(N=7,8\right.$, respectively) and salt-loaded ( $\mathrm{NaCl}, N=5,7$, respectively) rats determined by Western blot following $\mathrm{BS}^{3}$ surface protein crosslinking. Inset, Representative Western blots of SON tissue from a control rat treated with the membrane impermeant crosslinking agent $\mathrm{BS}^{3}$ and probed with antisera to GluA2 and $\beta$-actin. Two GluA2 bands were detected: a high molecular weight band representing the crosslinked surface protein aggregate $(\mathrm{S})$ and a band at the predicted molecular weight for GluA2 ( 100 kDa) that represents the unmodified intracellular pool (I). $\beta$-Actin served as an intracellular control and was found at its predicted molecular weight ( $\sim 40 \mathrm{kDa}$ ), confirming the lack of crosslinking of intracellular proteins. $\boldsymbol{D}$, Surface-to-intracellular (S/I) protein ratios determined following BS $^{3}$ surface protein crosslinking for GluA1-GluA4 AMPA receptor subunits in SON punches from control and salt-loaded $(\mathrm{NaCl})$ rats. Despite the increase in total GluA1 protein, there was no change in the subunit $\mathrm{S} / \mathrm{I}$ ratios between SON tissues from control and salt-loaded rats for any of the AMPA receptor subunits; $* p<0.05$.

corded in slices from OT-RFP rats, which showed a $93 \%$ increase in SEPSC frequency, from $1.5 \pm 0.2$ to $2.9 \pm 0.6$ $\mathrm{Hz}\left(t_{(10)}=2.5, p<0.05\right)$, and a $20 \%$ increase in the sEPSC amplitude, from $19.6 \pm 1.1$ to $23.5 \pm 1.1 \mathrm{pA}\left(t_{(10)}\right.$ $=2.4, p<0.05)$, in slices from salt-loaded compared to control rats.

The increase in SEPSC frequency in SON neurons following salt loading could be due to an increase in the probability of glutamate release from existing synapses or to an increase in the number of glutamatergic synapses. To determine whether the increase in glutamatergic synaptic inputs was caused by an increase in the probability of glutamate release, we performed a paired-pulse analysis on eEPSCs. The paired-pulse ratio did not differ between neurons from the control and salt-loaded groups (Fig. 3B). Thus, the paired/pulse ratios in SON neurons from control and salt-loaded rats were $1.3 \pm 0.2$ and 1.2 \pm 0.2 , respectively, in VP neurons from VP-eGFP rats (unpaired $t$ test, $t_{(16)}=1.01, p=0.32$ ) and $1.3 \pm 0.2$ and $1.1 \pm 0.1$, respectively, in OT neurons from OT-RFP rats $\left(t_{(6)}=1.06, p=0.33\right)$. These findings suggest that the increase in sEPSC frequency is not caused by an increase in the probability of glutamate release, but is due rather to an increased number of glutamate release sites. There were no differences in the sEPSC and paired-pulse measures between identified VP and OT neurons, so VP and OT neurons were pooled in subsequent analyses, unless otherwise stated.

The increase in GluA1 surface and intracellular protein with no change in GluA1 mRNA or GluA2, GluA3 or GluA4 protein or mRNA expression suggested a post-transcriptional increase in the GluA1-to-GluA2 ratio. GluA2lacking AMPA receptors are calcium-permeable and generate synaptic currents that display a voltagedependent inward rectification (Hollmann et al., 1991). We next determined the contribution of GluA2-lacking AMPA receptors to glutamatergic synaptic transmission in magnocellular neurons in the SON by analyzing the current- voltage relations of AMPA receptor-dependent eEPSCs. We recorded the AMPA receptor-mediated eEPSCs at holding potentials $(\mathrm{Vms})$ of -60 and $+40 \mathrm{mV}$ and calculated the AMPA current rectification index as the peak eEPSC amplitude at $-60 \mathrm{mV} /$ the peak eEPSC amplitude at $+40 \mathrm{mV}$. In a subset of neurons, we recorded AMPA receptor-mediated eEPSCs at Vms ranging from -60 to $+40 \mathrm{mV}$ in $20-\mathrm{mV}$ incremental steps to generate current- 

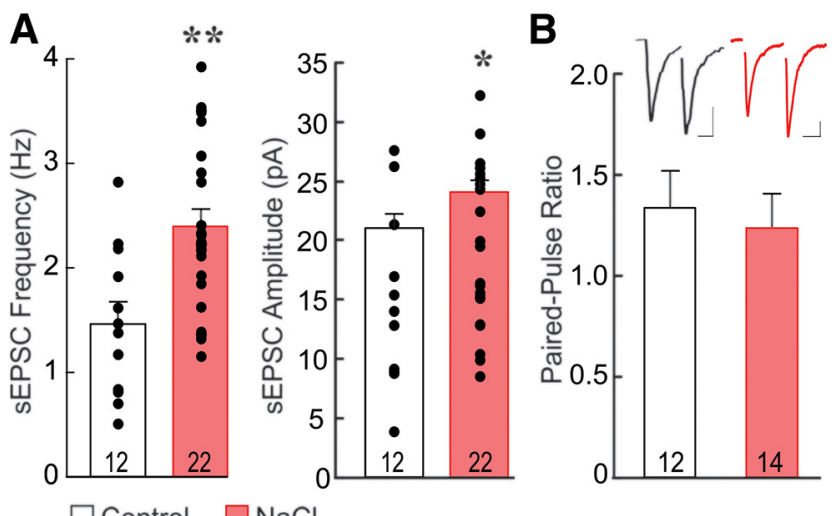

$\square$ Control $\square \mathrm{NaCl}$
C

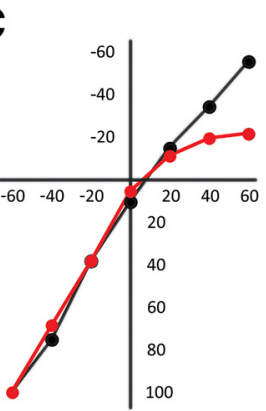

D

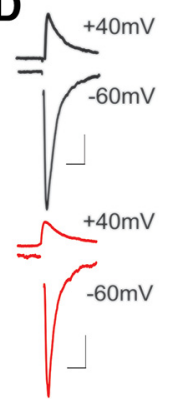

$\mathbf{E}$

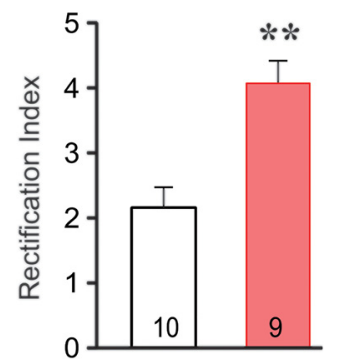

Figure 3. Increase in inwardly rectifying AMPA receptor signaling following salt loading. $\boldsymbol{A}$, Scatter plots of individual neuronal means and group means of sEPSC frequencies and amplitudes. Identified VP neurons recorded in slices from salt-loaded VPeGFP rats $(\mathrm{NaCl})$ showed a significant increase in the mean sEPSC frequency and amplitude compared to the control group. $\boldsymbol{B}$, The paired-pulse ratio of eEPSCs (inset) was unchanged following salt loading, suggesting that the increased glutamatergic synaptic activity was not due to a change in the probability of glutamate release. $\boldsymbol{C}$, The eEPSC current-voltage relationship showed inward rectification at $\mathrm{Vm}>0 \mathrm{mV}$ in SON neurons from salt-loaded rats (red curve, $n=6$ ) but not controls (black curve, $n=4$ ). The mean I-V curves are group averages of normalized individual I-V curves, expressed as percent of eEPSC recorded at $-60 \mathrm{mV}$. $\boldsymbol{D}$, Representative AMPA receptor-mediated eEPSC responses recorded at holding potentials of $-60 \mathrm{mV}$ and $+40 \mathrm{mV}$ in SON neurons from control and salt-loaded rats. $\boldsymbol{E}$, The rectification index (eEPSC amplitude at $-60 \mathrm{mV} / \mathrm{eEPSC}$ amplitude at $+40 \mathrm{mV}$ ) increased in SON neurons from salt-loaded rats, suggesting the emergence of calcium-permeable AMPA receptorcontaining glutamate synapses with salt loading. VP and OT neurons were pooled together for panels $\boldsymbol{B}-\boldsymbol{E}$. Numerals in bars represent recorded cell numbers; $* p<0.05$, $* * p<0.01$. Scale bars $=100 \mathrm{pA}, 20 \mathrm{~ms}$.

-voltage curves for the synaptic AMPA current. The current-voltage relationship of AMPA eEPSCs was nearly linear in SON neurons from control rats, suggesting little or no contribution of rectifying AMPA receptors to glutamatergic synaptic transmission in SON neurons under control conditions, but showed a significant inward rectification at $\mathrm{Vm}>0 \mathrm{mV}$ in SON neurons from salt-loaded rats (Fig. $3 C$ ). The rectification index was increased from $2.2 \pm 0.3$ in SON neurons from control rats to $4.0 \pm 0.3$ in SON neurons from salt-loaded rats (unpaired $t$ test, $t_{(17)}=$ $4.1, p<0.001$; Fig. 3D,E). This indicated that there is a significant increase in the rectifying AMPA receptor con- tribution to excitatory synaptic currents in SON neurons following chronic salt loading, suggesting an increase in calcium-permeable AMPA receptors.

We next examined the effect of the selective antagonist of GluA2-lacking, calcium-permeable AMPA receptors NAS on both sEPSCs and eEPSCs in SON magnocellular neurons from control and salt-loaded rats. NAS $(100 \mu \mathrm{M})$ had no effect on SEPSCs and eEPSCs in SON neurons from control rats, but caused a robust suppression of sEPSCs and eEPSCs in SON neurons in slices from saltloaded rats. Thus, bath application of NAS was without effect on the frequency ( $94 \%$ of baseline, paired $t$ test, $t_{(4)}$ $=1.27, p=0.27)$ or amplitude $\left(94 \%\right.$ of baseline, $t_{(4)}=$ $0.91, p=0.39$ ) of sEPSCs in SON neurons from control rats, but caused a significant decrease in the frequency (63\% of baseline, paired $t$ test, $\left.t_{(18)}=5.6, p<0.001\right)$ and amplitude $\left(80 \%\right.$ of baseline, $\left.t_{(18)}=3.3, p<0.05\right)$ of sEPSCs in SON neurons from salt-loaded rats (Fig. $4 A, B$ ). Similarly, NAS caused a non-significant decrease in the eEPSC amplitude in SON neurons from control rats $(94 \%$ of baseline, paired $t$ test, $t_{(9)}=2.1, p=0.06$ ), but caused a robust decrease in the eEPSC amplitude in neurons from salt-loaded rats $\left(68 \%\right.$ of baseline, $t_{(9)}=3.9, p=$ 0.008; Fig. 4C). NAS had no effect on the paired-pulse ratios in the SON neurons from either the control or the salt-loaded group (paired $t$ test, $p>0.05$; Fig. 4C), indicating again that the salt loading-induced synaptic plasticity is not due to an increase in the probability of presynaptic glutamate release.

Current-voltage analysis of eEPSCs during NAS application revealed a loss of the inward rectification of the AMPA currents in SON neurons from salt-loaded rats (one-way ANOVA, $F_{(3,28)}=7.67, p<0.001$ ). Thus, NAS reversed the increase in the eEPSC rectification index from $4.1 \pm 0.4$ to $2.6 \pm 0.2$ (post hoc Tukey's test, $p<$ 0.01 ) in SON neurons from salt-loaded rats, while it was without effect on the eEPSC rectification index in SON neurons from control rats (post hoc Tukey's test, $p=$ 0.519; Fig. 4D). The increase in the sensitivity of EPSCs to NAS and the NAS-induced reversal of the inward rectification of EPSCs in SON neurons from salt-loaded rats suggest that there is an induction of calcium-permeable AMPA receptors at glutamate synapses by salt loading, which is consistent with the increase in the GluA1-toGluA2 ratio of the AMPA receptors following salt loading. The linearity of the AMPA current-voltage relationship and the insensitivity of the AMPA currents to NAS in SON neurons from control rats suggest a relative lack of calcium-permeable AMPA receptors at glutamate synapses under control osmotic conditions.

If the salt loading-induced plasticity is not due to an increase in the probability of glutamate release, then the modulation of sEPSC frequency by NAS is likely to be a postsynaptic effect, since spontaneous excitatory synaptic activity in magnocellular neurons is generated almost entirely by spike-independent glutamate release (Kombian et al., 2000; Boudaba et al., 2003; Hirasawa et al., 2004). If this is the case, then the reduction in SEPSC frequency caused by blocking calcium-permeable AMPA receptors in magnocellular neurons from salt-loaded rats, 

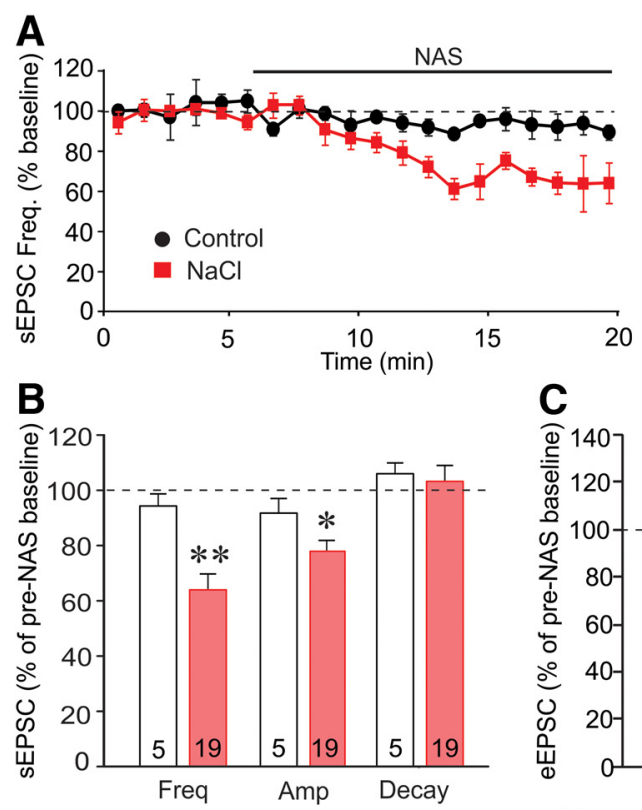
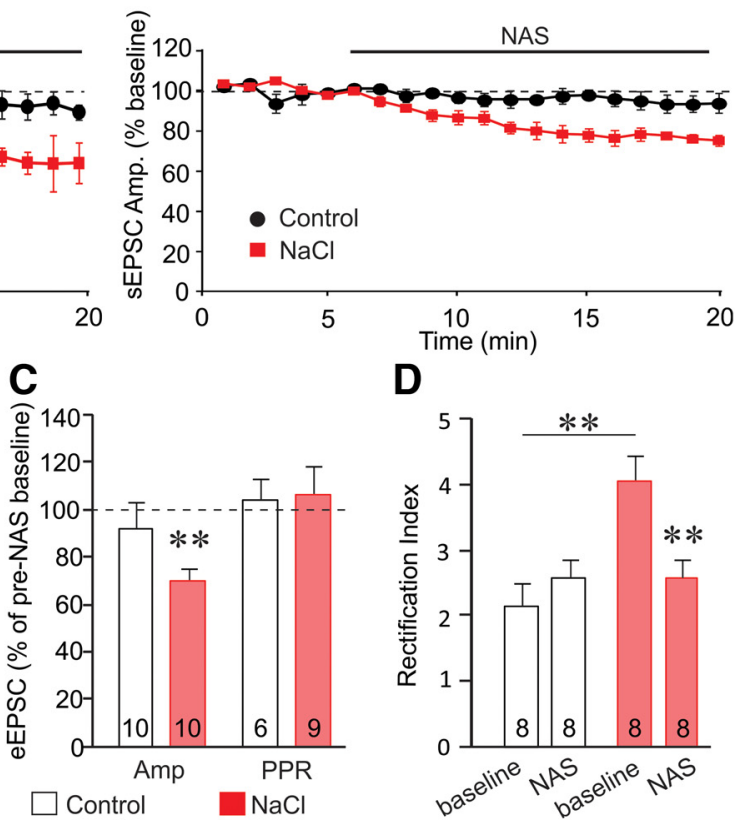

D

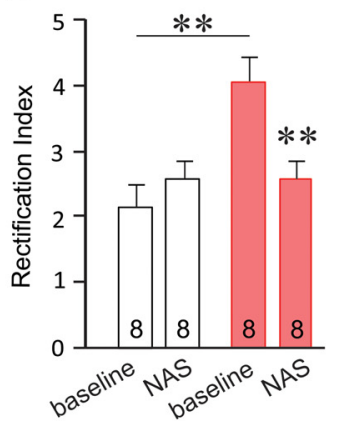

Figure 4. Change in EPSC sensitivity to the calcium-permeable AMPA receptor antagonist NAS following salt loading. $\boldsymbol{A}$, NAS reduced the mean frequency (left) and amplitude (right) of sEPSCs over time in SON neurons from salt-loaded (NaCl) rats, but not in SON neurons from control rats. $\boldsymbol{B}$. The effect of NAS on mean sEPSC frequency (Freq), amplitude (Amp), and decay time (Decay) in SON neurons from salt-loaded rats $(\mathrm{NaCl})$ and control rats, expressed as a percentage of baseline. NAS decreased the sEPSC frequency and amplitude in SON neurons from salt-loaded rats but not control rats. $\boldsymbol{C}$, NAS caused a decrease in the mean amplitude of eEPSCs in SON neurons from salt-loaded rats, but not control rats. NAS had no effect on the paired-pulse ratio of eEPSCs (PPR) in SON neurons from either control or salt-loaded rats. $\boldsymbol{D}$, NAS had no effect on the eEPSC rectification index in SON neurons from control rats, but reversed the increase in the rectification index in SON neurons from salt-loaded rats. Numerals in bars represent recorded cell numbers; $* p<0.05, * * p<0.01$ compared to control or baseline.

but not in neurons from control rats, suggests silencing of the newly formed excitatory synapses. The new glutamate synapses formed during salt loading appear, then, to be composed of homomeric GluA1, calcium-permeable AMPA receptors, whereas the "old" synapses in neurons from the dehydrated rats and nearly all the synapses in neurons from control rats are composed of GluA2containing, calcium-impermeable AMPA receptors. If the new synapses added following salt loading are dependent on the new surface area added by hypertrophy of the magnocellular neurons (Theodosis et al., 1998), and only the new synapses are composed of calcium-permeable AMPA receptors, then the increased sensitivity of the eEPSCs to the calcium-permeable AMPA-receptor antagonist should be tightly correlated to the increase in magnocellular neuron surface area. To test this, we performed a Pearson correlation between the NAS effect on eEPSCs and the cell surface area of recorded cells, measured as membrane capacitance, in oxytocinergic and vasopressinergic SON neurons from control and salt-loaded rats. There was a highly significant correlation between membrane capacitance and NAS sensitivity of the eEPSCs in the SON neurons (correlation coefficient $=0.8, n=19, p$ $<0.001$; Fig. 5). A significant correlation was also observed between the membrane capacitance and the NAS sensitivity of the sEPSCs (correlation coefficient $=0.3, n$ $=23, p<0.01$ ). The correlation between the increase in surface area and the relative increase in the NAS sensitivity of EPSCs in SON neurons from salt-loaded rats suggests that most of the additional glutamate synapses that were newly formed on the expanded membrane surface during salt loading are composed of calciumpermeable AMPA receptors.

Dendritic protein synthesis can play a critical role in synaptic plasticity (Zukin, 2009; Cajigas et al., 2010; Swanger and Bassell, 2013; Leal et al., 2014). Increased translation of GluA1 has been linked to the increased insertion of homomeric GluA1 calcium-permeable AMPA

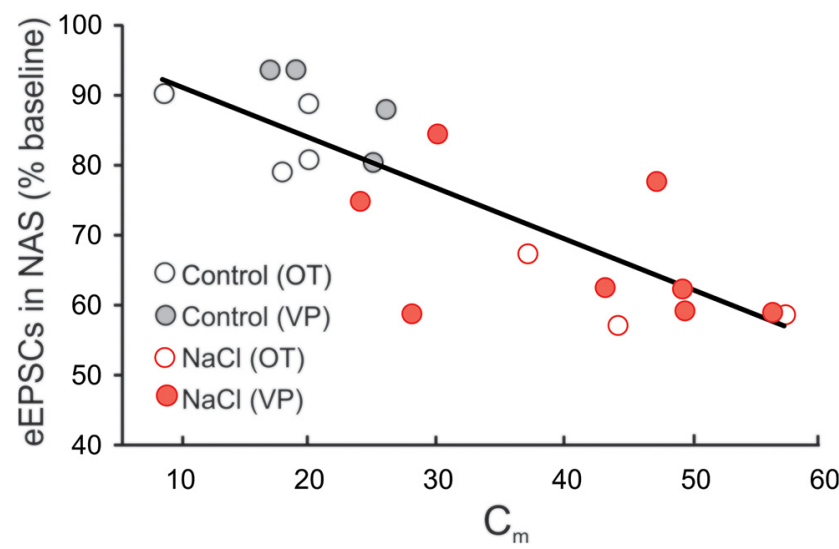

Figure 5. Correlation of the membrane surface area to NAS sensitivity. There was a significant correlation between the increase in magnocellular neuron surface area, as measured by membrane capacitance $\left(\mathrm{C}_{\mathrm{m}}\right)$, and the change in eEPSC amplitude in NAS. 
receptors (Sutton et al., 2006; Chen et al., 2014; Stefanik et al., 2018). Interestingly, a recent study found that protein synthesis is also required for the maintenance of elevated calcium-permeable AMPA receptor levels in nucleus accumbens synapses (Scheyer et al., 2014). Therefore, we next investigated the role of rapid protein translation in the AMPA receptor plasticity seen in the chronic salt-loading rat model. In these experiments, brain slices from salt-loaded and control rats were preincubated for $1-2 \mathrm{~h}$ in the protein synthesis inhibitor $\mathrm{CHX}$ $(25 \mu \mathrm{M})$ before performing whole-cell recordings. There was a significant difference in the effect of $\mathrm{CHX}$ pretreatment on sEPSCs in SON neurons (one-way ANOVA, $F_{(3,30)}$ $=6.5, p<0.05$ ). Post hoc Dunnett's tests revealed a significant increase in the baseline SEPSC frequency in SON neurons from salt-loaded rats compared to the baseline SEPSC frequency in control rats $(\mathrm{NaCl}$ baseline: $2.7 \pm 0.3 \mathrm{~Hz}$ vs control baseline: $1.7 \pm 0.2 \mathrm{~Hz} ; p<0.05$, Dunnett's test; Fig. $6 A$ ), as described above. While blocking protein synthesis with $\mathrm{CHX}$ pretreatment had no effect on the SEPSC frequency in SON neurons from the control rats (control $\mathrm{CHX}: 1.6 \pm 0.2$ vs control baseline: $1.7 \pm 0.2$ $\mathrm{Hz}$; n.s., Dunnett's test), CHX returned the sEPSC frequency in the SON neurons from the salt-loaded rats to a frequency not significantly different from the baseline sEPSC frequency in the control rats $(\mathrm{NaCl} \mathrm{CHX}: 2.0 \pm 0.2$ $\mathrm{Hz}$ vs control baseline: $1.7 \pm 0.2 \mathrm{~Hz}$, n.s., Dunnett's test; Fig. 6A).

The CHX effect on AMPA-dependent eEPSC current- voltage relations also differed between the SON neurons from the control and salt-loaded groups. $\mathrm{CHX}$ pretreatment had no effect on the eEPSC current-voltage relationship in SON neurons from control rats, but significantly attenuated the voltage-dependent inward rectification in AMPA-mediated eEPSCs in SON neurons from salt-loaded rats (Fig. $6 B, C$ ). The $\mathrm{CHX}$ pretreatment decreased the AMPA current rectification index in SON neurons from the salt-loaded group (one-way ANOVA $\left.F_{(7,74)}=9.258, p<0.001\right)$ to a level comparable to that in SON neurons from the control group $(\mathrm{NaCl}+\mathrm{CHX}: 2.8 \pm$ 0.3 vs control: $2.9 \pm 0.2$, n.s., post hoc Dunnett's test; Fig. $6 \mathrm{C})$. Furthermore, the $\mathrm{CHX}$ pretreatment occluded the effect on the rectification index of NAS blockade of calcium-permeable AMPA receptors in neurons from saltloaded rats $(\mathrm{NaCl}+\mathrm{CHX}: 2.8 \pm 0.3$ vs $\mathrm{NaCl}+\mathrm{CHX}+\mathrm{NAS}$ : $2.4 \pm 0.2$; Fig. $6 C$ ), indicating that the observed reversal of the increase in rectification index by blocking protein synthesis was due to the loss of calcium-permeable AMPA receptor signaling.

We also tested for a transcription dependence of the AMPA receptor plasticity induced by chronic salt loading. Blocking gene transcription with the transcription inhibitor ACT $(25 \mu \mathrm{M})$ had no effect on the inward rectification seen in SON neurons from salt-loaded rats $(\mathrm{NaCl}+\mathrm{ACT} 4.5 \pm$ 0.3 vs control, $p<0.05$, post hoc Dunnett's test), nor did it affect the NAS sensitivity of the AMPA receptormediated synaptic currents in these neurons, as NAS reduced the rectification index to a level not significantly different from the rectification index of SON neurons from control rats $(\mathrm{NaCl}+\mathrm{ACT}+\mathrm{NAS} 2.9 \pm 0.3$ vs control, n.s.,
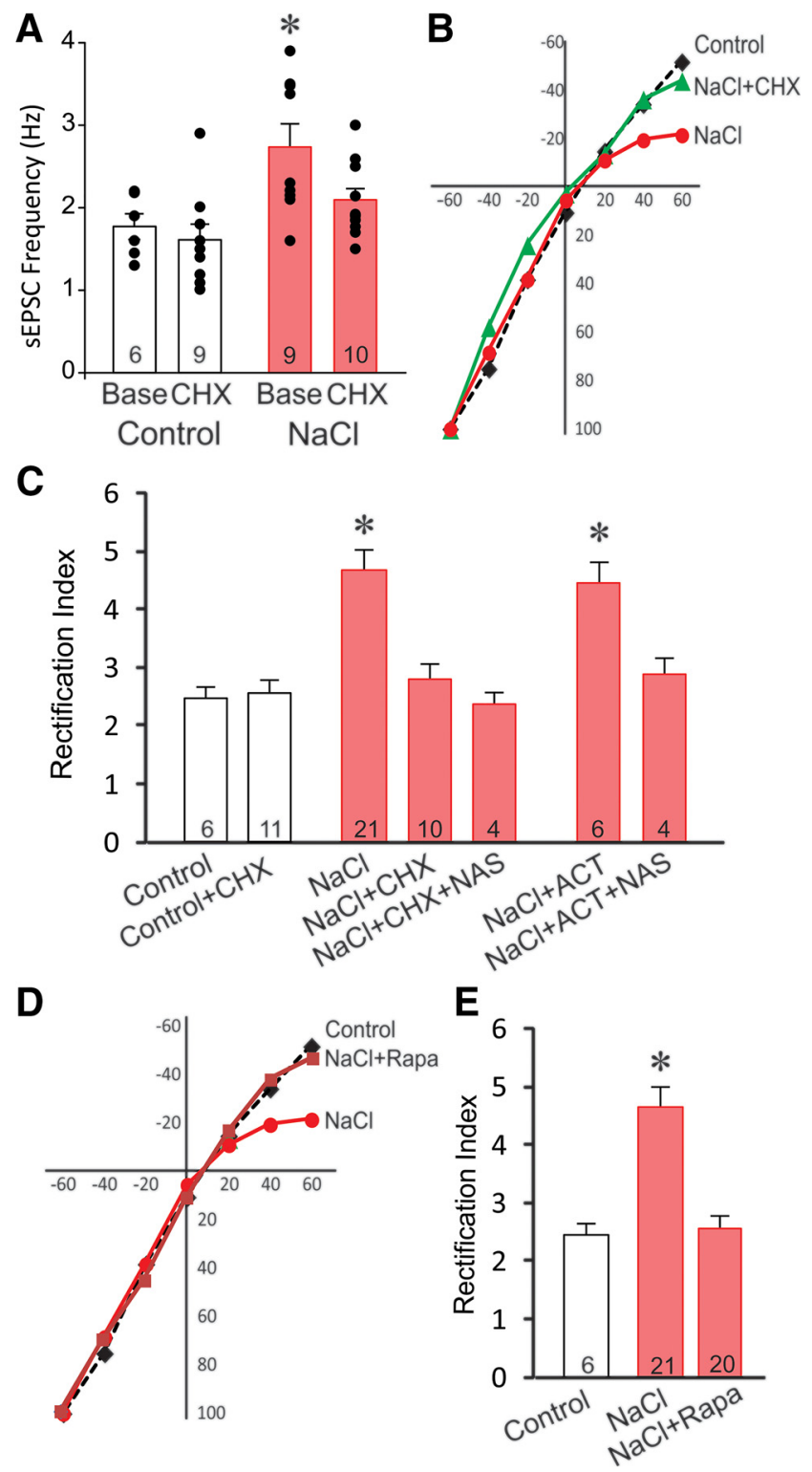

Figure 6. The maintenance of new inwardly rectifying AMPA currents is dependent on protein synthesis. $\boldsymbol{A}$, Blocking protein synthesis with $\mathrm{CHX}(25 \mu \mathrm{M})$ had no effect on SEPSC frequency in SON neurons from control rats, but reversed the increase in sEPSC frequency induced in SON neurons by salt loading to the control baseline level (one-way ANOVA followed by Dunnett's test). $\boldsymbol{B}$, Blocking protein synthesis with $\mathrm{CHX}(\mathrm{NaCl}+\mathrm{CHX})$ eliminated the increase in eEPSC inward rectification seen in SON neurons from salt-loaded rats $(\mathrm{NaCl})$ compared to SON neurons from control rats. $\boldsymbol{C}, \mathrm{CHX}$ had no effect on the rectification index in eEPSCs in SON neurons from control rats (control $+\mathrm{CHX}$ ), but reversed the increase in the rectification index $(\mathrm{NaCl}+\mathrm{CHX})$ and occluded the effect of $\mathrm{NAS}(\mathrm{NaCl}+\mathrm{CHX}+\mathrm{NAS})$ in SON neurons from salt-loaded rats. Inhibition of gene transcription with ACT $(25 \mu \mathrm{M})$ had no effect on the eEPSC rectification index $(\mathrm{NaCl}+\mathrm{ACT})$ and did not prevent the NAS-induced reduction in the rectification index $(\mathrm{NaCl}+\mathrm{ACT}+\mathrm{NAS})$ in neurons from saltloaded rats. $\boldsymbol{D}, \boldsymbol{E}$, Blocking $\mathrm{mTOR}$ activity with rapamycin ( $\mathrm{NaCl}+\mathrm{Rapa}$ ) blocked the eEPSC inward rectification induced by salt loading and returned the eEPSC rectification index to the control level (one-way ANOVA followed by Dunnett's test); $* p<$ 0.05 . 
post hoc Dunnett's test; Fig. 6C). Together, these findings indicated that the increase in calcium-permeable AMPA synaptic currents in slices from salt-loaded rats is dependent on protein translation but not on gene transcription.

mTOR is a protein kinase in the PI3 kinase family that has been implicated in BDNF-dependent dendritic protein synthesis (Tang and Schuman, 2002; Takei et al., 2004). The rapid silencing of calcium-permeable AMPA receptor currents by inhibiting protein synthesis suggests a local dendritic translation mechanism. Therefore, we tested for the mTOR dependence of the maintenance of AMPA receptor plasticity following chronic salt loading by inhibiting mTOR activity with Rapa. Pre-incubation of slices for $1-2 \mathrm{~h}$ in Rapa (500 nM) significantly attenuated the voltage-dependent inward rectification of AMPA eEPSCs in SON neurons from salt-loaded rats (Fig. 6D,E). Rapa pretreatment decreased the AMPA current rectification index in neurons from salt-loaded rats to a value that did not differ from the rectification index of AMPA currents recorded in neurons from control rats ( $\mathrm{NaCl}+\mathrm{Rap}: 2.6 \pm$ 0.1 vs control, n.s., post hoc Dunnett's test). These results suggest that dendritic mTOR-dependent protein translation plays a critical role in the maintenance of the homomeric GluA1 AMPA receptor-containing glutamate synapses induced by chronic salt loading.

\section{Discussion}

Sustained physiologic activation of the hypothalamicneurohypophysial system leads to pronounced neuronalglial remodeling and synaptic plasticity in SON and PVN magnocellular neurons (Bonfanti and Theodosis, 2009; Tasker et al., 2017). Among the plastic changes, glutamatergic synapses on magnocellular neuronal somata/proximal dendrites increase in number in response to chronic salt loading (Miyata et al., 1994b; Hatton, 1997), lactation (El Majdoubi et al., 1996), and repeated restraint stress (Miyata et al., 1994a), and glutamatergic synaptic inputs are enhanced during chronic salt loading (Di and Tasker, 2004) and lactation (Stern et al., 2000; Oliet et al., 2001). We hypothesized that this increase in excitatory synaptic innervation during salt loading would be accompanied by altered AMPA receptor expression and signaling.

The lack of significant regulation of any of the AMPA receptor subunit mRNAs detected with qPCR was unexpected and suggested that any change in glutamate receptor expression that accompanies the increased glutamate synapse numbers during salt loading must be mediated by post-transcriptional regulation of protein expression. Our Western blot analysis supported this by revealing an increase in GluA1 surface and intracellular protein, with no change in the expression of the other three AMPA receptor subunits. This indicated, therefore, that chronic salt loading regulates AMPA receptor expression at the level of protein translation, not transcription, and that it induces an increase in GluA1 subunits, but not in GluA2, GluA3, or GluA4 subunits. This in turn suggested the possibility of an increase in the relative contribution of AMPA receptors that contain GluA1 but not GluA2 subunits after salt loading (i.e., calcium-permeable AMPA receptors). Our whole-cell recordings of EPSCs confirmed an increase in the proportion of GluA1containing, GluA2-lacking AMPA receptors at glutamate synapses induced by chronic salt loading. Salt loading resulted in an increase in the sEPSC frequency and amplitude, but did not cause a change in the glutamate release probability measured by paired-pulse analysis, consistent with our previous findings ( $\mathrm{Di}$ and Tasker, 2004) and suggesting a change in presynaptic glutamate release sites (i.e., synapse number; Hatton, 1997; Theodosis et al., 1998). Salt loading also resulted in a robust increase in the sensitivity of pharmacologically isolated synaptic AMPA currents to NAS, a selective antagonist of GluA2-lacking, calcium-permeable receptors, and an increase in the AMPA current inward rectification at membrane potentials $>0 \mathrm{mV}$, which was reversed by NAS. NAS caused a reduction in the amplitude of eEPSCs and a reduction in both the amplitude and frequency of SEPSCs in SON neurons from salt-loaded rats, while it had no effect on eEPSCs or SEPSCs in SON neurons from control rats. Since the increase in the proportion of NAS-sensitive AMPA currents in slices from salt-loaded rats may reflect the increase in glutamate synapses induced by salt loading, this suggests that the new synapses formed during chronic dehydration express predominantly calciumpermeable AMPA receptors. The strong correlation between the proportion of AMPA current blockade by NAS and the membrane capacitance of SON neurons suggests that the increase in membrane surface area is correlated with the increase in synaptic calcium-permeable AMPA receptors, again supporting the notion that the new glutamate synapses covering the added membrane surface are predominantly composed of GluA1 receptors. The most compelling evidence for the new synapses being composed of GluA1 homomeric receptors was found by blocking calcium-permeable AMPA receptors and inhibiting protein synthesis, which reversed the salt loadinginduced increase in SEPSC frequency and AMPA current rectification. These observations together strongly suggest that the synapses newly formed during salt-loading are composed of GluA1 homomeric AMPA receptors, while the old glutamate synapses are composed of GluA2-containing AMPA receptors. Evidence for GluA2containing synapses and GluA2-lacking glutamate synapses co-innervating the same neurons has been shown previously in hippocampal neurons and retinal ganglion cells (Lerma et al., 1994; Zhang et al., 1995).

Previous studies have reported that OT neurons display AMPA receptor-mediated mEPSCs with larger amplitude, faster decay kinetics and stronger inward rectification than VP neurons, which suggests that OT and VP neurons may have a different GluA2 composition in synaptic AMPA receptors (Stern et al., 1999). The increase in glutamatergic synaptic inputs to magnocellular neurons during lactation was reported to be specific to OT neurons (EI Majdoubi et al., 1996; Stern et al., 2000). We were not able to distinguish between OT and VP neurons in our molecular analyses; however, we identified OT and VP neurons in our electrophysiological experiments and found no obvious difference in the effect of salt loading on AMPA currents in the two cell types. The source of this discrep- 
ancy may stem from differences in the plastic changes in glutamatergic synapses and receptors induced by different physiologic challenges (i.e., lactation vs salt loading). Indeed, we have found that lactation induces changes in AMPA receptor subunit protein expression (S. Wang and J.G. Tasker unpublished observations) which are different from those reported here that are induced by salt loading.

Studies have shown that the transient expression of calcium-permeable, GluA2-lacking receptors might provide an important route for calcium entry during synapse maturation and a possible mechanism for short- and long-term plasticity in developing networks (Rozov and Burnashev, 1999; Liu and Cull-Candy, 2000). While magnocellular neurons do not exhibit prominent dendritic spines, they show significant changes in excitatory synapse number with salt loading, and the increase in calcium-permeable AMPA receptors and resulting changes in calcium permeability of glutamate synapses during salt loading may play an important functional role in the synaptic plasticity of glutamate synapses in these cells. AMPA receptor-mediated, calciumdependent synaptic plasticity may take the place of NMDA receptor-dependent plasticity under conditions of astrocyte retraction (e.g., during salt loading and lactation), when NMDA receptor mechanisms are diminished due to the loss of the astrocytic source of the NMDA receptor co-agonist D-serine (Panatier et al., 2006).

The change in AMPA receptor-mediated synaptic currents with salt loading was reversed by blocking protein synthesis, but was insensitive to inhibition of transcription, suggesting that continuous protein translation is required to maintain synaptic function at the new synapses formed during salt loading. This is similar to the elevation in calciumpermeable AMPA receptor-mediated currents observed in the nucleus accumbens after cocaine withdrawal, which is also reversed by inhibiting protein synthesis prior to recordings (Scheyer et al., 2014). However, while the increase in calcium-permeable AMPA receptor levels in the nucleus accumbens persists for months during cocaine withdrawal (Wolf, 2016), the new glutamate synapses in magnocellular neurons induced by salt-loading, which we show here to comprise calcium-permeable AMPA receptors, are lost within days of reversal of hyperosmotic conditions (Miyata et al., 1994b). Blocking protein synthesis silenced the calcium-permeable AMPA receptor synapses in the SON neurons from salt-loaded rats, which suggests that the AMPA receptors formed at new excitatory synapses during salt loading are highly labile.

The production of new calcium-permeable AMPA receptors during salt loading is likely to be due to local dendritic protein synthesis, since it was blocked by inhibiting mTOR activity. The silencing of the salt loadinginduced excitatory synapses could be due to structural reorganization of the afferent axons and loss of synaptic contacts (i.e., presynaptic), or to the trafficking of the calcium-permeable AMPA receptors out of the synapses (i.e., postsynaptic). It is unlikely that the synaptic silencing is due to physical pruning of afferent axon terminals because the structural changes induced by salt loading take several days, not hours, to return to control levels following termination of the hyperosmotic stimulation (Miyata et al., 1994b). The silencing of the excitatory synapses with protein synthesis blockade, therefore, is likely to be the result of AMPA receptor trafficking out of the synapse. The newly formed GluA1 homomeric glutamatergic synapses, therefore, are highly labile, subject to silencing with modulation of protein synthesis and trafficking, while the older, GluA*-GluA2 heteromeric synapses are more stable.

The calcium permeability and the lability of the newly formed glutamate synapses may contribute to the statedependent plasticity of the magnocellular system that is highly responsive to changing osmotic conditions. Glutamate receptor activation is necessary for the neuronalglial structural plasticity induced by osmotic stimulation (Langle et al., 2003). The increase in calcium influx through the new calcium-permeable AMPA receptors, therefore, may contribute to the inductive and/or maintenance mechanism(s) responsible for the neuronal-glial structural reorganization and the synaptic facilitation seen in magnocellular neurons during chronic hyperosmotic challenge.

\section{References}

Al-Ghoul WM, Meeker RB, Greenwood RS (1997) Differential expression of five $\mathrm{N}$-methyl-D-aspartate receptor subunit mRNAs in vasopressin and oxytocin neuroendocrine cells. Brain Res Mol Brain Res 44:262-272.

Arnauld E, Wattiaux JP, Arsaut J, Rostène W, Vincent JD (1993) Alterations in vasopressin and oxytocin messenger RNA in the rat supraoptic nucleus during dehydration-rehydration evaluated by in situ hybridization and northern blotting. Neurosci Lett 149:177181.

Bonfanti L, Theodosis DT (2009) Polysialic acid and activitydependent synapse remodeling. Cell Adh Migr 3:43-50.

Borges K, Dingledine R (1998) AMPA receptors: molecular and functional diversity. Prog Brain Res 116:153-170.

Boudaba C, Di S, Tasker JG (2003) Presynaptic noradrenergic regulation of glutamate inputs to hypothalamic magnocellular neurones. J Neuroendocr 15:803-810.

Boudreau AC, Milovanovic M, Conrad KL, Nelson C, Ferrario CR, Wolf ME (2012) A protein cross-linking assay for measuring cell surface expression of glutamate receptor subunits in the rodent brain after in vivo treatments. Curr Protoc Neurosci Chapter 5:Unit 5.30.1-19.

Brownstein MJ, Russell JT, Gainer H (1980) Synthesis, transport, and release of posterior pituitary hormones. Science 207:373-378.

Cajigas IJ, Will T, Schuman EM (2010) Protein homeostasis and synaptic plasticity. EMBO J 29:2746-2752.

Chen L, Lau AG, Sarti F (2014) Synaptic retinoic acid signaling and homeostatic synaptic plasticity. Neuropharmacology 78:3-12.

Choe KY, Han SY, Gaub P, Shell B, Voisin DL, Knapp BA, Barker PA, Brown CH, Cunningham JT, Bourque CW (2015) High salt intake increases blood pressure via BDNF-mediated downregulation of KCC2 and impaired baroreflex inhibition of vasopressin neurons. Neuron 85:549-560.

Dachtler J, Glasper J, Cohen RN, Ivorra JL, Swiffen DJ, Jackson AJ, Harte MK, Rodgers RJ, Clapcote SJ (2014) Deletion of $\alpha$-neurexin II results in autism-related behaviors in mice. Transl Psychiatry 4:e484.

Di S, Tasker JG (2004) Dehydration-induced synaptic plasticity in magnocellular neurons of the hypothalamic supraoptic nucleus. Endocrinology 145:5141-5149.

Dingledine R, Borges K, Bowie D, Traynelis SF (1999) The glutamate receptor ion channels. Pharmacol Rev 51:7-61.

El Majdoubi M, Poulain DA, Theodosis DT (1996) The glutamatergic innervation of oxytocin- and vasopressin-secreting neurons in the 
rat supraoptic nucleus and its contribution to lactation-induced synaptic plasticity. Eur J Neurosci 8:1377-1389.

Gainer H, Wray S (1994) Cellular and molecular biology of oxytocin and vasopressin. In: The physiology of reproduction, pp 10991129. New York, NY: Raven Press.

Ginsberg SD, Price DL, Blackstone CD, Huganir RL, Martin LJ (1995) The AMPA glutamate receptor GluR3 is enriched in oxytocinergic magnocellular neurons and is localized at synapses. Neuroscience 65:563-575.

Gribkoff VK, Dudek FE (1988) The effects of the excitatory amino acid antagonist kynurenic acid on synaptic transmission to supraoptic neuroendocrine cells. Brain Res 442:152-156.

Hatton Gl (1997) Function-related plasticity in hypothalamus. Annu Rev Neurosci 20:375-397.

Hattori Y, Shibuya I, Tanaka K, Kabashima N, Ueta Y, Yamashita H (1998) lonotropic and metabotropic glutamate receptor agonistinduced $[\mathrm{Ca} 2+] \mathrm{i}$ increase in isolated rat supraoptic neurons. J Neuroendocrinol 10:383-389.

Hirasawa M, Schwab Y, Natah S, Hillard CJ, Mackie K, Sharkey KA, Pittman QJ (2004) Dendritically released transmitters cooperate via autocrine and retrograde actions to inhibit afferent excitation in rat brain. J Physiol 559:611-624.

Hollmann M, Hartley M, Heinemann S (1991) Ca2+ permeability of KA-AMPA-gated glutamate receptor channels depends on subunit composition. Science 252:851-853.

Isaac JTR, Ashby MC, McBain CJ (2007) The role of the GluR2 subunit in AMPA receptor function and synaptic plasticity. Neuron 54:859-871.

Katoh A, Fujihara H, Ohbuchi T, Onaka T, Hashimoto T, Kawata M, Suzuki H, Ueta Y (2011) Highly visible expression of an oxytocinmonomeric red fluorescent protein 1 fusion gene in the hypothalamus and posterior pituitary of transgenic rats. Endocrinology 152:2768-2774.

Kindlundh-Högberg AM, Blomqvist A, Malki R, Schiöth HB (2008) Extensive neuroadaptive changes in cortical gene-transcript expressions of the glutamate system in response to repeated intermittent MDMA administration in adolescent rats. BMC Neurosci 9:39.

Kombian SB, Hirasawa M, Mouginot D, Chen X, Pittman QJ (2000) Short-term potentiation of miniature excitatory synaptic currents causes excitation of supraoptic neurons. J Neurophysiol 83:25422553.

Langle SL, Poulain DA, Theodosis DT (2003) Induction of rapid, activity-dependent neuronal-glial remodelling in the adult rat hypothalamus in vitro. Eur J Neurosci 18:206-214.

Leal G, Comprido D, Duarte CB (2014) BDNF-induced local protein synthesis and synaptic plasticity. Neuropharmacology 76:639656.

Lerma J, Morales M, Ibarz JM, Somohano F (1994) Rectification properties and $\mathrm{Ca} 2+$ permeability of glutamate receptor channels in hippocampal cells. Eur J Neurosci 6:1080-1088.

Liu SQ, Cull-Candy SG (2000) Synaptic activity at calciumpermeable AMPA receptors induces a switch in receptor subtype. Nature 405:454-458.

Luther JA, Daftary SS, Boudaba C, Gould GC, Halmos KC, Tasker JG (2002) Neurosecretory and non-neurosecretory parvocellular neurones of the hypothalamic paraventricular nucleus express distinct electrophysiological properties. J Neuroendocrinol 14: 292-932.

Martin LJ, Blackstone CD, Levey Al, Huganir RL, Price DL (1993) AMPA glutamate receptor subunits are differentially distributed in rat brain. Neuroscience 53:327-358.

Meeker RB, Swanson DJ, Hayward JN (1989) Light and electron microscopic localization of glutamate immunoreactivity in the supraoptic nucleus of the rat hypothalamus. Neuroscience 33:157167.

Meeker RB, Swanson DJ, Greenwood RS, Hayward JN (1993) Quantitative mapping of glutamate presynaptic terminals in the supraoptic nucleus and surrounding hypothalamus. Brain Res 600: 112-122.
Miyata S, Itoh T, Matsushima O, Nakashima T, Kiyohara T (1994a) Not only osmotic stress but also repeated restraint stress causes structural plasticity in the supraoptic nucleus of the rat hypothalamus. Brain Res Bull 33:669-675.

Miyata S, Nakashima T, Kiyohara T (1994b) Structural dynamics of neural plasticity in the supraoptic nucleus of the rat hypothalamus during dehydration and rehydration. Brain Res Bull 34:169-175.

Nissen R, Hu B, Renaud LP (1994) N-methyl-D-aspartate receptor antagonist ketamine selectively attenuates spontaneous phasic activity of supraoptic vasopressin neurons in vivo. Neuroscience 59:115-120.

Nissen R, Hu B, Renaud LP (1995) Regulation of spontaneous phasic firing of rat supraoptic vasopressin neurones in vivo by glutamate receptors. J Physiol 484:415-424.

Oliet SH, Piet R, Poulain DA (2001) Control of glutamate clearance and synaptic efficacy by glial coverage of neurons. Science 292: 923-926.

Pak CW, Currás-Collazo MC (2002) Expression and plasticity of glutamate receptors in the supraoptic nucleus of the hypothalamus. Microsc Res Tech 56:92-100.

Panatier A, Theodosis DT, Mothet JP, Touquet B, Pollegioni L, Poulain DA, Oliet SHR (2006) Glia-derived D-serine controls NMDA receptor activity and synaptic memory. Cell 125:775-784.

Petralia RS, Wenthold RJ (1992) Light and electron immunocytochemical localization of AMPA-selective glutamate receptors in the rat brain. J Comp Neurol 318:329-354.

Petralia RS, Wang YX, Wenthold RJ (1994) Histological and ultrastructural localization of the kainate receptor subunits, KA2 and GluR6/7, in the rat nervous system using selective antipeptide antibodies. J Comp Neurol 349:85-110.

Piet R, Poulain DA, Oliet SHR (2002) Modulation of synaptic transmission by astrocytes in the rat supraoptic nucleus. J Physiol Paris 96:231-236.

Poulain DA, Wakerley JB (1982) Electrophysiology of hypothalamic magnocellular neurones secreting oxytocin and vasopressin. Neuroscience 7:773-808.

Rozov A, Burnashev N (1999) Polyamine-dependent facilitation of postsynaptic AMPA receptors counteracts paired-pulse depression. Nature 401:594-598.

Sato K, Kiyama H, Tohyama M (1993) The differential expression patterns of messenger RNAs encoding non- $\mathrm{N}$-methyl-D-aspartate glutamate receptor subunits (GluR1-4) in the rat brain. Neuroscience 52:515-539.

Scheyer AF, Wolf ME, Tseng KY (2014) A protein synthesisdependent mechanism sustains calcium-permeable AMPA receptor transmission in nucleus accumbens synapses during withdrawal from cocaine self-administration. J Neurosci 34: 3095-3100.

Sherman TG, Day R, Civelli O, Douglass J, Herbert E, Akil H, Watson SJ (1988) Regulation of hypothalamic magnocellular neuropeptides and their mRNAs in the Brattleboro rat: coordinate responses to further osmotic challenge. J Neurosci 8:3785-3796.

Stefanik MT, Milovanovic M, Werner CT, Spainhour JCG, Wolf ME (2018) Withdrawal from cocaine self-administration alters the regulation of protein translation in the nucleus accumbens. Biol Psychiatry 84:223-232.

Stern JE, Galarreta M, Foehring RC, Hestrin S, Armstrong WE (1999) Differences in the properties of ionotropic glutamate synaptic currents in oxytocin and vasopressin neuroendocrine neurons. $J$ Neurosci 19:3367-3375.

Stern JE, Hestrin S, Armstrong WE (2000) Enhanced neurotransmitter release at glutamatergic synapses on oxytocin neurones during lactation in the rat. J Physiol 526:109-114.

Sutton MA, Ito HT, Cressy P, Kempf C, Woo JC, Schuman EM (2006) Miniature neurotransmission stabilizes synaptic function via tonic suppression of local dendritic protein synthesis. Cell 125:785-799.

Swanger SA, Bassell GJ (2013) Dendritic protein synthesis in the normal and diseased brain. Neuroscience 232:106-127.

Takei N, Inamura N, Kawamura M, Namba H, Hara K, Yonezawa K, Nawa H (2004) Brain-derived neurotrophic factor induces mam- 
malian target of rapamycin-dependent local activation of translation machinery and protein synthesis in neuronal dendrites. J Neurosci 24:9760-9769.

Tang SJ, Schuman EM (2002) Protein synthesis in the dendrite. Philos Trans R Soc London Ser B Biol Sci 357:521-529.

Tasker JG, Dudek FE (1991) Electrophysiological properties of neurones in the region of the paraventricular nucleus in slices of rat hypothalamus. J Physiol 434:271-293.

Tasker JG, Voisin DL, Armstrong WE (2017) The Cell Biology of Oxytocin and Vasopressin Cells. In: Hormones, Brain and Behavior (Pfaff DW, Joëls M, eds), 3 Ed, Vol 3, pp 305-336. Amsterdam: Academic Press.

Theodosis DT, El Majdoubi M, Pierre K, Poulain DA (1998) Factors governing activity-dependent structural plasticity of the hypothalamoneurohypophysial system. Cell Mol Neurobiol 18:285-298.

Ueta Y, Fujihara H, Serino R, Dayanithi G, Ozawa H, Matsuda K, Kawata M, Yamada J, Ueno S, Fukuda A, Murphy D (2005) Transgenic expression of enhanced green fluorescent protein enables direct visualization for physiological studies of vasopressin neurons and isolated nerve terminals of the rat. Endocrinology 146: 406-413.

van den Pol AN, Wuarin JP, Dudek FE (1990) Glutamate, the dominant excitatory transmitter in neuroendocrine regulation. Science 250:1276-1278.

van den Pol AN, Hermans-Borgmeyer I, Hofer M, Ghosh P, Heinemann S (1994) lonotropic glutamate-receptor gene expression in hypothalamus: localization of AMPA, kainate, and NMDA receptor RNA with in situ hybridization. J Comp Neurol 343:428-444.

Van Tol HHM, Voorhuis D, Burbach JPH (1987) Oxytocin gene expression in discrete hypothalamic magnocellular cell groups is stimulated by prolonged salt loading. Endocrinology 120:71-76.

Verbalis JG (1993) Osmotic inhibition of neurohypophysial secretion. Ann NY Acad Sci 689:146-160.

Washburn MS, Numberger M, Zhang S, Dingledine R (1997) Differential dependence on GluR2 expression of three characteristic features of AMPA receptors. J Neurosci 17:9393-9406.

Watanabe M, Inoue Y, Sakimura K, Mishina M (1993) Distinct distributions of five $\mathrm{N}$-methyl-D-aspartate receptor channel subunit mRNAs in the forebrain. J Comp Neurol 338:377-390.

Wolf ME (2016) Synaptic mechanisms underlying persistent cocaine craving. Nat Rev Neurosci 17:351-365.

Wuarin JP, Peacock WJ, Dudek FE (1992) Single-electrode voltageclamp analysis of the $\mathrm{N}$-methyl-D-aspartate component of synaptic responses in neocortical slices from children with intractable epilepsy. J Neurophysiol 67:84-93.

Zhang D, Sucher NJ, Lipton SA (1995) Co-expression of AMPA kainate receptor-operated channels with high and low $\mathrm{Ca} 2+$ permeability in single rat retinal ganglion cells. Neuroscience 67:177188.

Zukin RS (2009) Signals, synapses, and synthesis: how new proteins control plasticity. Front Neural Circuits 3:14. 